BABELAO 1 (2012), p. 77-98

(C) ABELAO (Belgium)

\title{
The Phoenician Inscription of Eshmunazar An Attempt at Vocalization
}

By

Jean-Claude Haelewyck

FNRS et Université de Louvain, Louvain-la-Neuve

$\mathrm{V}$ ocalizing a Phoenician text is not a superfluous exercise. Instead of staying on the surface of such a text, it allows an in-depth analysis and interpretation. Of course this vocalization will always be hypothetic. However if a sound method is used, the results can be interesting. The method has already been developed in two previous articles ${ }^{1}$. It may be useful to recall here the major principles.

The method premises a great affinity between Hebrew and Phoenician. In general ancient Phoenician texts are not written with matres lectionis which could be a real help for the vocalization. The only way is to take a look at the historical grammar and at the ancient transcriptions. Almost all nouns and adjectives in Phoenician have a corresponding form in Hebrew lexicography. It is therefore relatively easy to find the patterns, the ground-forms

${ }^{1}$ J.-C. HAELEWYCK, «L'inscription phénicienne du sarcophage d'Ahiram. Un essai de vocalisation », Res Antiquae 5 (2008), p. 439-450; ID., "L'inscription phénicienne de Tabnit (KAI 13). Essai de vocalisation », Res Antiquae 8 (2011), p. 1-12. 
(schèmes in French, Stammbildungen in German) on which these words were built. And indeed the historical grammar of Hebrew devotes a large part of its work identifying these primitive patterns. From this point of view two major works are essential: the historical grammar of Hebrew by Bauer and Leander, and the last edition of the Hebrew dictionary by Koehler and Baumgartner ${ }^{2}$. The latter follows in general the observations of Bauer-Leander, but it also includes the results of more recent research. Once the information concerning Hebrew has been collected we then turn to Phoenician. The main work here is the grammar of Friedrich and Röllig updated by Maria Giulia Amadasi Guzzo ${ }^{3}$. By the means of Assyrian, Greek and Latin transcriptions, it is possible to know the evolution of the primitive patterns in Phoenician. For example the word ' If " ox » is originally a monosyllabic qatl as attested by the known forms ${ }^{4}$. The Greek transcription $\lambda \alpha \sigma o v v-$ $\alpha \lambda \phi$ for the name of the plant (literally ox-tongue), and also the name of the letter $\alpha \dot{\alpha} \lambda \phi \alpha$ indicate that the word has remained monosyllabic without the anaptyx of a vowel ${ }^{5}$. Are we allowed to extrapolate this conclusion to all the monosyllabic qatl forms? I think so, unless we explicitly find a counter-example. We do know, via the transcriptions, that some words have evolved differently in Phoenician. For example the word malk «king» ap-

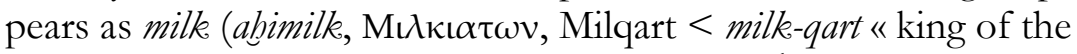
city ») indicating a transition from qatl to qitl $^{6}$. It also happens that the transcriptions give conflicting information. For example the word $\approx r^{\prime}$ "seed» is attested as zura (Pliny, XXIV, 71) and as $\zeta \varepsilon 0 \alpha$ (Dioscorides, II, 103). How can we decide in this case on the primitive pattern: qutl or qitl? A second difficulty is that the transcriptions are often very late compared to the dates attributed to the inscriptions. It is therefore necessary to consider the possibility of changes in ancient vocalism. Fortunately the grammar of Friedrich-Röllig provides keys to understanding this evolution. It should also be noted that the transmission itself of the transcriptions may have suffered accidents: the Phoenician extracts in the Poenulus were copied by generations of copyists who did not understand a single word.

\footnotetext{
${ }^{2}$ H. BAUER - P. LEANDER, Historische Grammatik der bebräischen Sprache des Alten Testaments, Hildesheim, 1965 (= Halle, 1922); L. KOEHLER - W. Baumgartner, Hebräisches und aramäisches Lexikon zum Alten Testament, dritte Auflage, Leiden, 1995.

${ }^{3}$ J. FRIEDRICH - J.-W. RÖLLIG, Phönizisch-punische Grammatik. 3. Aufl., neu bearbeitet von M.G. Amadasi Guzzo unter Mitarbeit von W.R. Mayer (Analecta orientalia 55), Rome, 1999.

${ }^{4}$ KOEHLER-BAUMGARTNER, sub voce.

${ }^{5}$ Cf. FRIEDRICH-RÖLLIG, \ 193-195.

${ }^{6}$ Although it may be the opposite: for A. SPERBER, «Hebrew based upon Greek and Latin Transliterations ", Hebrew Union College Annual 12/13 (19371938), p. 237, the primitive form is qitl. BAUER-LEANDER, p. 457r, think that the primitive form is qatil (as in Arabic, malik). In any case these considerations are irrelevant to our research. There is no doubt that the word was vocalized milk in Phoenician.
} 
For the verbs we can proceed in the same way using the primitive forms such as grammar can reconstruct them beyond Hebrew. In this area the reconstitution of the Canaanite verbal system proposed by Meyer ${ }^{7}$ can complete the analysis made by Bauer-Leander. We will compare these forms with the data from transcriptions. But one must be careful not to project onto Phoenician texts what is problematic in Hebrew, such as the forms with waw-inversive the existence of which is highly challenged today $^{8}$. Our vocalization also assumes that, unlike archaic Phoenician, standard Phoenician (which includes the inscription of Eshmunazar) has lost the final short vowel of the third person perfect: qatal instead of qatala. We also consider with FriedrichRöllig that for the nouns with suffixes a distinction is still made between nominative/accusative (connecting vowel $-a$-) and genitive (connecting vowel $-i$-).

The sarcophagus was contructed in Egypt in black basalt and transported to Sidon to contain the body of Eshmunazar II (465451), king of Sidon and son of king Tabnit ${ }^{9}$. It was unearthed in 1855 in a site near Sidon and offered by the Ottoman Sultan to Napoleon III. It is now located in the Louvre Museum in Paris.

The stonecutter began to write just below the head but, due to a serious mistake, he started his work again on the top of the sarcophagus (with a few errors). Originally the sarcophagus contained a hieroglyphic text that was replaced by the Phoenician inscription. The text below comes from the editions of DonnerRöllig (KAI 14) and Gibson ${ }^{10}$.

\section{Text}

1. BYRH BL BŠNT 'SR W'RB' 14 LMLKY MLK 'ŠMN'ZR MLK ȘDNM

2. BN MLK TBNT MLK ṢDNM DBR MLK 'ŠMN'ZR MLK SWDNM L'MR NGZLT

3. BL 'TY BN MSK YMM 'ZRM YTM BN 'LMT WŠKB 'NK BHLT Z WBQBR Z

\footnotetext{
${ }^{7}$ R. MEYER, Hebräische Grammatik, Berlin - New York, 1992 (= 1969-1982).

8 J. TROPPER, "Althebräisches und semitisches Aspektsystem », Zeitschrift für Althebraistik 11 (1998), p. 153-190; T.D. ANDERSEN, «The Evolution of the Hebrew Verbal System », Zeitschrift für Althebraistik 13 (2000), p. 1-66; A. VAN DE SANDE, Nouvelle perspective sur le système verbal de l'hébreu ancien. Les formes * qatala, *yaqtul et *yaqtulu (Publications de l'Institut Orientaliste de Louvain 57), Louvain-la-Neuve, 2008.

${ }^{9}$ For the chronology of the kings of Sidon, see J. ELAYI, «An Updated Chronology of the Reigns of Phoenician Kings during the Persian Period (539333 BCE) », Transeuphratène 32 (2006), p. 11-43 (with bibliography and references to her preceedings articles).

${ }^{10}$ H. DONNER - W. RÖLLIG, Kanaanäische und aramäische Inschriften, I-III, Wiesbaden, 1966-1969, p. 19-23 (= KAI); J.C.L. GIBSON, Textbook of Syrian Semitic Inscriptions, vol. 3, Oxford, 1982, p. 105-114 (hereafter cited as GIBSON, TSSI).
} 
4. BMQM 'Š BNT QNMY 'T KL MMLKT WKL 'DM 'L YPTH 'YT MŠKB Z W

5. 'L YBQŠ BN MNM K 'Y ŠM BN MNM W'L YŠ' 'YT HLT MŠKBY W'L Y'M

6. SN BMŠKB Z 'LT MŠKB ŠNY 'P 'M 'DMM YDBRNK 'L TŠM' BDNM KKL MMLKT W

7. $\mathrm{KL}$ 'DM 'Š YPTH 'LT MŠKB Z 'M 'Š YŠ' 'YT HLT MŠKKBY 'M 'Š Y'MSN BM

8. ŠKB Z 'L YKN LM MŠKB 'T RP'M W'L YQBR BQBR W'L YKN LM BN WZR'

9. THTNM WYSGRNM H'LNM HQDŠM 'T MMLK $<\mathrm{T}>$ 'DR 'Š MŠL BNM LQ

10. ȘTNM 'YT MMLKT 'M 'DM H' 'Š YPTH 'LT MŠKB $Z$ 'M 'Š YŠ' 'YT

11. HLT Z W'YT ZR MML<K>T H' 'M 'DMM HMT 'L YKN LM ŠRŠ LMT W

12. PR LM'L WT'R BHYM TḤT ŠMŠ K 'NK NḤN NGZLT BL 'TY BN MS

13. $\mathrm{K}$ YMM 'ZRM YTM BN 'LMT 'NK K 'NK 'ŠMN'ZR MLK SWDM BN

14. MLK TBNT MLK ȘDNM BN BN MLK 'ŠMN'ZR MLK SWDM W'MY 'M'ŠTRT

15. KHNT 'ŠTRT RBTN HMLKT BT MLK 'ŠMN'ZR MLK ȘDNM 'M BNN 'YT BT

16. 'LNM 'YT [BT 'ŠTR]T BṢDN 'RS YM WYŠR'N 'YT 'ŠTRT ŠMM 'DRM W'NHN

17. 'Š BNN BT L'ŠMN [Š]R QDŠ $N$ YDLL BHR WYŠBNY ŠMM 'DRM W'NHN 'Š BNN BTM

18. L'LN ȘDNM BṢDN 'RS YM BT LBL ȘDN WBT L'ŠTRT ŠM B'L W'D YTN LN 'DN MLKM

19. 'YT D'R WYPY 'RSTT DGN H'DRT 'Š BŠD ŠRN LMDT 'ṢMT 'Š PeLT WYSPNNM

20. 'LT GBL 'RS LKNNM LṢDNM L'L[M] QNMY 'T KL MMLKT WKL 'DM 'L YPTH 'LTY

21. W'L Y'R 'LTY W'L Y'MSN BMŠKB Z W'L YŠ' 'YT HLT MŠKBY LM YSGRNM

22. 'LNM HQDŠM 'L WYQṢN HMMLKT H' WH'DMM HMT WZR'M L'LM

\section{Translation}

1. In the month of Bul, in the fourteenth year of the reign of king Eshmunazar, king of the Sidonians, 2. son of king Tabnit, king of the Sidonians, king Eshmunazar, king of the Sidonians, said as follows: I was carried away 3. before my time, son of a limited number of short days (or: son of a limited number of days I was cut off), an orphan, the son of a widow, and I am lying in this coffin and in this tomb, 4. in a place which I have built. Whoever you are, king or (ordinary) man, may he (sic!) not open 
this resting-place 5. and may he not search in it after anything because nothing whatsoever has been placed into it. And may he not move the coffin of my resting-place, nor carry me $\mathbf{6}$. away from this resting-place to another resting-place. Also if men talk to you do not listen to their chatter. For every king and 7. every (ordinary) man, who will open what is above this resting-place, or will lift up the coffin of my resting-place, or will carry me away from 8. this resting-place, may they not have a resting-place with the Rephaïm, may they not be buried in a tomb, and may they not have a son or offspring 9. after them. And may the sacred gods deliver them to a mighty king who will rule them in order 10. to exterminate them, the king or this (ordinary) man who will open what is over this resting-place or will lift up 11. this coffin, and (also) the offspring of this king or of those (ordinary) men. They shall not have root below or 12. fruit above or appearance in the life under the sun. For I who deserve mercy, I was carried away before my time, son of a limited 13. number of short days (or: son of a limited number of days I was cut off), I an orphan, the son of a widow. For I, Eshmunazar, king of the Sidonians, son of 14. king Tabnit, king of the Sidonians, grandson of king Eshmunazar, king of the Sidonians, and my mother Amo[t]astart, 15. priestess of Ashtart, our lady, the queen, daughter of king Eshmunazar, king of the Sidonians, (it is we) who have built the temples 16. of the gods, [the temple of Ashtar]t in Sidon, the land of the sea. And we have placed Ashtart (in) the mighty heavens (or: in Shamem-Addirim?). And it is we 17. who have built a temple for Eshmun, the prince of the sanctuary of the source of Ydll in the moutains, and we have placed him (in) the mighty heavens (or: in Shamem-Addirim?). And it is we who have built temples 18. for the gods of the Sidonians in Sidon, the land of the sea, a temple for Baal of Sidon, and a temple for Ashtart, the Name of Baal. Moreover, the lord of kings gave us 19. Dor and Joppa, the mighty lands of Dagon, which are in the Plain of Sharon, as a reward for the brilliant action I did. And we have annexed them 20. to the boundary of the land, so that they would belong to the Sidonians for ever. Whoever you are, king or (ordinary) man, do not open what is above me 21. and do not uncover what is above me and do not carry me away from this resting-place and do not lift up the coffin of my resting-place. Otherwise, 22. the sacred gods will deliver them and cut off this king and those (ordinary) men and their offspring for ever. 


\section{Vocalization ${ }^{11}$}

1. biyarh bûl bišanôt 'asr we'arba' lemulkiyû milk 'èsmûn'azar milk sîdônim 2. bin milk tabnît milk sîdônîm dabar milk 'èsmûn'azar milk sîdônim lìmôr nagzalti 3. bilô 'ittiya bin masok yômîm 'azzîrîm yatum bin 'almat wešôkéb 'anôkề bihallot zô webiqabr zè 4. bimaqôm 'és banîtî qenummiya 'atta kul mamlokêt wekul 'adom 'al yiptab 'iyat miškob zè $\boldsymbol{5}$.

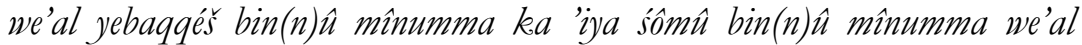
yiśśo' 'iyat hallot miškobiya we'al 6. ya 'musénî bimiškob zè 'alôt miškob šenîy 'ap 'îm 'adomîm yedabberînakâ 'al tišma" baddanôm kakul mamlokêt 7. wekul 'adom 'és yiptah 'alôt miškob zè 'îm 'és yiśsón 'iyat ballot miškobiya 'îm 'és ya'musénî 8. bimiškob zè 'al yakûn lôm miškob 'ét rapa'îm we'al yiqqaberû biqabr we'al yakûnû lôm bin wezar' 9. tabténôm weyasgirûnôm hâalônim haqqadošm 'ét mamlokîu $<t>$ 'addîr 'és môsél bin(n)ôm 10. laqișsotinôm/ laqassôtinôm 'iyat mamlokût 'im 'adom bû̀'a 'és yiptah 'alôt miškob zè 'îm 'és yiśśo' 'iyat 11. hallot zè we'iyat zar'

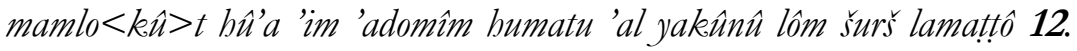
we parî lama'lô wetu'r babayyîm taḅt samšs ka 'anôkề nâbâan nagzalti bilô 'ittiya bin 13. masok yômîm 'azzîrim yatum bin 'almat 'anôkî̀ ka 'anôkî̀ 'ềmûn'az̧ar milk sîdônim bin 14. milk tabnit milk sîdônîm bin bin milk 'ềmûn'azar milk sîdônim we'ammaya 'amot'aštart 15. kôhant 'aštart rabbotanû bammilkot bat milk 'èsmûn'azar milk sîdônîm 'SY baninû 'iyat bîté 16. 'alônîm 'iyat < bit 'aštar>t bisîdôn 'ars yim weyôsibnûu 'iyat 'aštart šamém 'addîrim we'anabnû 17. 'éš banînû bît la'êsmûn <śa $>$ r qudš 'în ydll

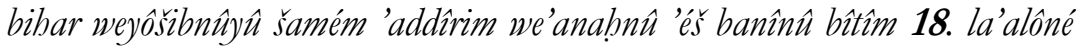
sîdônim bișidôn 'ars yim bit laba'l șidôn webit la'aštart sim ba'l we'ôd yatan lanû 'adôn milkîm 19. 'iyat du'r weyapay 'arsôt dagôn hâ'addîrôt 'és biśadé šarôn lamiddot 'asûmot 'éš pa'altî weyasapnûném 20. 'alôt gubûl(ế) 'arṣ lakûniném lașîidônim la'ôlo $<m>$ qenummiya 'atta kul mamlokût wekul 'adom 'al yiptah 'alôtiya 21. we'al ya 'ar 'alôtiya we'al ya'musénî bimiškob zè we'al yišso' 'iyat hallot miškobiya lamâ yasgirûnôm 22. 'alônîm haqqadoš̀m 'illè weyeqașşuna bammamlokêt bû'a wehâ'adomîm bumatu wezarồm la'ôlom.

\section{Commentary}

1-2. BYRH BL BŠNT 'SR W'RB' 14 LMLKY MLK 'ŠMN'ZR MLK SDNM BN MLK TBNT MLK SDNM DBR MLK 'ŠMN'ZR MLK ṢDNM L'MR (biyarḅ bûl bišanôt 'asr we'arba' lemulkiyû milk 'èsmûn'azar milk sîdônîm bin milk tabnît milk sîdônim dabar milk 'èsmûn'azar milk sîdônim lìmôr) "In the month of Bul, in the fourteenth year of the reign of king Eshmunazar, king of the Sidonians, son of king Tabnit, king of

${ }^{11}$ In this article we have reduced the vocalism to the following vowels: a/â (patah, qames), e (vocalic shewa; nothing for the silent one), è (segol), é (șere), $\mathrm{i} / \hat{i}$ (hireq), o (holem; exponent for qameș hatufu), u/û (shureq, qibbuṣ). We assume that the complexity of the Hebrew vocalic system (as notated by the Naqdanim of Tiberias) is absent from the Phoenician. 
the Sidonians, king Eshmunazar, king of the Sidonians, said as follows ». The word $y r b$ " month» is a monosyllabic qatl in Hebrew (yerab) $)^{12}$, hence the vocalization biyarh. We assume that the prepositions have retained their original form $b i-, l a-, k a^{-13}$. Bul is the eighth month of the Canaanite calendar (cf. 1 Kings 6:38:

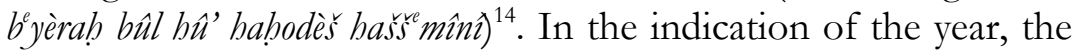
word is a plural here (bišanot), while in Hebrew it is usually singu-

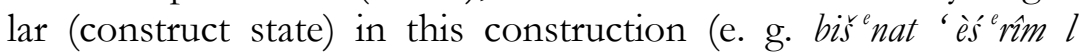
'yarob'am, 1 Kings 15:9). In the nouns with nun as third radical, in the singular the nun is assimilated to the feminine ending -t ( $s^{a} a t$ «year» $[<\check{s}$ attu $<*$ santu $])$ but it is maintained in the plural ${ }^{15}$. The vocalization $\check{s} a t$ is confirmed by Punic sath. The Latin transcriptions sanu (!), sanuth, and the Punic forms s"n't, s"nwt, indicate a pronunciation sanôt (the vowel - $a$ - is rendered by 'än in the Punic forms!). The cardinal number ' $s r$ "ten», here written with $-s$ while we would expect $-s_{-16}^{16}$, is a qatl-form, hence the vocalization 'asr. In the Semitic languages the numeral 'arba' "four» always appears with a prosthetic alef (Ugaritic, Hebrew, Aramaic, Syriac, Arabic, Epigraphic South-Arabic, Ethiopic; it is not written in Accadian erbe, arba'u, only because Accadian has no sign to render the phonem). First spelled out in words the number is then rendered in numeric signs: I III $\neg$, i.e. $10+3+1$. The sequence of the chronological indications is rather unusual: we would first expect the year and then the month ${ }^{17}$. With Donner-Röllig ${ }^{18}$, we may interpret lmlky as an infinitive construct (mulk) followed by a $3 \mathrm{~m}$. sg. pronominal suffix (proleptic as for example in Syriac) here vocalized $-y \hat{u}^{19}$. It is more probably the substantive mulk « reign» (cf. Num 24:7) already present in the inscription of Ahiram. The theophoric name 'êsmûn'az̧ar combines two words: the name of the god Ešmûn, god of medecine and maybe also of vegetation, which is identified with Asclepius, and the verb 'azar «to help »; thus « Ešmûn has helped (me) ». Ešmûn ${ }^{20}$ is known in Syria from the third millennium onwards, but little is known about him. Even the etymology of the name is a disputed question. Several explanations have been proposed: reference is made to tamân

12 BAUER-LeAnder, p. 457 r (originally a disyllabic qatil, cf. Arabic). As said above (p. 78), the monosyllabic qatl remains the same in Phoenician, cf. FRIEDRICH-RÖLLIG, \ 193-195.

${ }^{13}$ Cf. FRIEDRICH-RÖLLIG, \ 251.

14 Thanks to 1 Kings 6:1-3.8 we know the names of four of them: Zîw, Ethanîm, Bûl, respectively the second, seventh and eighth month, to which can be added the sixth month Abîb (more often cited in the Bible).

${ }^{15}$ FRIEDRICH-RÖLLIG, $\int 230$ 2, which give another example: bat « daughter », plural banôt (cf. bynuthi « my daughters » in Poenulus 932). On the transcription sath, see ID., $₫ 24018$.

16 FRIEDRICH-RÖLLIG, \46b.

17 There are many examples in the Old Testament, cf. for Jeremiah alone $28: 1.17 ; 36: 9 ; 39: 1.2 ; 52: 4.31$. The reverse sequence is not unattested, cf. Gn $46: 15$.

${ }^{18} \mathrm{KAI}$, p. $20-21$.

${ }^{19}$ FrIEDRICH-RÖLLIG, $\int 1904 \beta$.

20 Cf. E. LIPIŃSKI (ed.), Dictionnaire de la civilisation phénicienne et punique, Turnhout, 1992, p. 158-160. 
« eight» (*tmn > šmn) with prosthetic alef, or to šem «name », or to samn « oil» (š̀mèn in Hebrew, qatl ${ }^{21}$ as in Accadian, Arabic), the latter could better suit his status as a god of medecine. The vocalization 'ěsmûn (šmûn after a vowel) is based on the following tran-

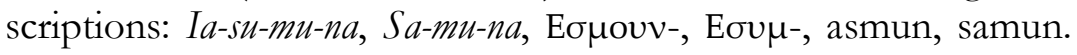
The element 'azar also appears in Aбoov $\beta \alpha \varsigma$, Azrubal where 'azar $+B a l$ Baal has helped» has become 'azr-Bal, pronounced 'azru$B a^{6}{ }^{2}$. We could also vocalize 'azor' ${ }^{23}$. There are indeed forms of the perfect in -o- and not in - $a-: v \alpha \delta \omega \mathrm{Q}$ " he made vow », Ba 'l-balos, Ba-al-ba-lu-su «Baal released», Baliaton = Ba l-yaton « Baal gave $»^{24}$. The verb $d b r$ « to talk, to say » appears a few times in Phoenician: for example in the Poenulus as duber/dobrim (qal active participle sg. and pl. = dôbér/dôb rim) and here. It may be either qal (dabar) or piel (dibberr, the vocalization of the piel is confirmed by the transcription $B \alpha \lambda \sigma \iota \lambda \lambda \eta \chi$ «Baal sent»). The Canaanite primitive form of the infinitive construct is qtul $\left(>\mathrm{Hebrew}^{\mathrm{e}} \mathrm{tol}^{25}\right)$. The expected form here would be la-'mor. However, two observations should be made. First the spelling liful (Poenulus 945/935) shows a shift from $l a-$ to $l i$ - as in Hebrew. Then the question arises: in the case of a Pe Alef verb, is the alef quiescent (as in $\mathrm{Hebrew}^{26}$ ) or not? In many cases there is an elision of the alef in nouns ${ }^{27}$. Presumably the same phenomenon occurs also with verbs, hence the vocalization li'môr (the form liful indicates moreover that the final syllabe is long).

2-4. NGZLT BL 'TY BN MSK YMM 'ZRM YTM BN 'LMT WŠKB 'NK BHLT Z WBQBR Z BMQM 'Š BNT (nagzalti bilô 'ittiya bin masok yômîm 'azzîrim yatum bin 'almat wešokéb 'anôkề bihallot zố webiqabr zè bimaqôm 'és banîtì) «I was carried away before my time, son of a limited number of short days (or: son of a limited number of days I was cut off), an orphan, the son of a widow, and I am lying in this coffin and in this tomb, in a place which I have built ». The major part of these two lines will be repeated in lines 12-13. The verb ngzlt is a 1st sg. nifal perfect. The root $g$ Zl (attested two times in Phoenician ${ }^{28}$ ) means « seize by force, acquire illegitimately» (qal) and «to be snatched (i.e. from life), to be carried away by a violent death » (nifal). It is also attested in Hebrew, frequently in qal ("tear away, seize, rob»), but there is only one clear case in the nifal: Prov 4:16: «their sleep is taken away " (KJV), " they are robbed of sleep » (NAS); the case of Micah 3:2 («who pluck off their skin» KJV, "who tear off their skin» NAS) is not clear. The vocalization nagzalti is con-

\footnotetext{
${ }^{21}$ BAUER-LEANDER, p. $456 \mathrm{j}$.

22 FRIEDRICH-RÖLLIG, $\int 96$ bis.

${ }^{23}$ With $K A I$, p. 21.

${ }^{24}$ FrIEDRICH-RÖLLIG, $\int 78 \mathrm{c}$.

${ }^{25}$ MEYER, \} 6 5 .

${ }^{26}$ MEYER, \ $771 \mathrm{~d}, \int 223 \mathrm{a}$.

${ }^{27}$ See examples in FREDRICH-RÖLLIG, $₫ 14$.

28 J.HoftiJzer - K. Jongeling, Dictionary of the North-West Semitic Inscriptions (Handbook of Oriental Studies 21), 2 vol., Leiden - New York - Köln, 1995 , p. 219 (hereafter cited as DNWSI).
} 
firmed by Tell-el-Amarna (EA 93,5) na-aq-sa-ap-ti = naqsapti $« \mathrm{I}$ was asked». In Hebrew there has been a shift from naqtalti to niqtalti. It is not clear if this shift has also occurred in Phoenician. It is possible but not certain. In the case of doubt we have kept the $n a$ - form. In the expression $b l$ ' $y, b l$ is certainly not the negation $b a l$, which is normally used before a verb or to negate a substantive (bal 'î́s «non-man»). Could it be the preposition bi- followed by the negation lô? There is a difficulty: this negation is totally unknown in Phoenician and in Punic. However, the expression has an excellent parallel in Eccles 7:17: lâmmâh tâmût belo' 'ittèkha "why should you die before your time? ». Ultimately we have chosen bilô. The noun "itt "time» is originally a qil-type noun with a feminine ending ${ }^{29} * i d t$, and after total regressive assimilation *idt becomes * itt-, ittiya with the $1 \mathrm{~m}$. sg. suffix. The word msk appears only in this inscription (lines 3 and 13). Its meaning is still unknown. Three etymological derivations have been proposed ${ }^{30}$ : from ske, from $s w k / s w k$ or from $s k y$, roots who evoke the idea of limitation ${ }^{31}$. The context invites us to understand «limited time, limited number». Could we have a maqtaltype noun (masok or masôk)? There is great hesitation about the analysis and meaning of ' 2 rm (known only by its two occurrences in this inscription) ${ }^{32}$. The word is either an adjective referring to yômîm or a verbal form. Traditionally it has been explained as an adjective meaning "short» ('azirim if qatil, 'azzîrim if qattî ${ }^{33}$ ). The meaning would be "son of a limited number of short days". Others prefer to interpret it as a verbal form of a root $\mathrm{rm}$ unattested in Phoenician but known in Hebrew ${ }^{34}$ and Arabic ${ }^{35}$ : either a $1 \mathrm{~m}$. sg. nifal imperfectif 'azzarém (*'anqatil > *'aqqatil > 'aqqatél), 'izarém (the two forms in ' $a$ - and in ' $i$ - are attested in Hebrew), or qal imperfective $1 \mathrm{~m}$. sg 'azrum ('aqtul). The nifal of the verb means «to be cut, cut off», and the qal «to cease ». The meaning would be « son of a limited number of days I was cut off/I stopped (living) ». Following a suggestion made by R.S. Tomback, E. Puech ${ }^{36}$ assumes that the word means a kind of sacrifice ('azorim or 'azarim, qatal-type), but what is the link with the context? Lipiński divides ${ }^{37}$ the text differently: $b n m$ sk $y \mathrm{~mm}$ 'rrm « with the sleep of a deaf (man) I must break off the days (of life) ». He interprets num as an infinitive. The verb is attested in Hebrew, Arabic, Aramaic,

\footnotetext{
${ }^{29}$ BAUER-LEANDER, p. 450 j. The qil-type nouns do not change in Phoenician, see for example 'iz: « strength », FRIEDRICH-RÖLLIG, \192 bis b.

${ }^{30}$ DNWSI, p. 664, see already KAI, p. 21.

31 See ske I in KOEHLER-BAUMGARTNER, p. 712; Hebrew śukh « to make a hedge » in Job 1:10; 3:23; Syriac sôkô" " end, limit, boundary ».

${ }^{32}$ DNWSI, p. 26-27.

33 These are the most attested patterns for the adjectives, cf. FRIEDRICHRÖLLIG, \ 196, 199.

34 Only two occurrences: Ps 90:5 (qal «thou hast swept them away») and 77:18 (poel « the clouds poured out water »).

35 KAZIMIRSKI, I, p. 987: « interrupt, stop ».

36 E. PUECH, recension of R.S. TOMBACK, A Comparative Semitic Lexicon of the Phoenician and Punic Languages, Revue Biblique 88 (1978), p. 99.

${ }^{37}$ E. LIPIŃSKI, «From Karatepe to Pyrgi: Middle Phoenician miscellanea », Rivista di Studi fenici 2 (1974), p. 45-61, in part. p. 56-57.
} 
and Ethiopic; in Akkadian the noun munattu "morning-sleep » derives from the same root. The sleep in question here is the sleep of deafness: sk must be related to the Akkadian sakku and the Arabic asakk, both meaning "deaf». The Hebrew equivalent of ytm "orphan" is yatôm (yatim in Arabic), a qatul-type noun ${ }^{38}$. There is no evidence on the vocalization of qatul-type nouns in Phoenician ${ }^{39}$. Hypothetically we assume that they remain qatul in Phoenician, hence yatum. The word 'lmt «widow» (Hebrew 'almânâb) is attested in Akkadian as almattu, the primitive form being likely *'almantu ('alman with feminine ending). We assume for the Phoenician the following evolution: 'almantu > 'almant $>$ 'almat $(t)^{40}$. When 'Ešmunazar presents himself as the son of a widow, he indicates that his father Tabnit was already dead when 'Ešmunazar was born. The word ḅlt « sarcophagus, coffin » occurs five time in Phoenician, and all of the occurrences are in this inscription. The meaning is clear. The word could derive from the root bll "pierce» well attested in the Semitic languages (Arabic balla, "pierce », billat « stone sarcophagus », ballat « gap, crack»; Aramaic halâl « empty space ») ${ }^{41}$. We could vocalize hallot. In Hebrew qèbèr «tomb » is originally a monosyllabic qat ${ }^{42}$, accordingly we vocalize qabr. The word mqm « place » comes from a root qwm, and is a maqtal-type $\operatorname{word}^{43}$ : maqwam, in Phoenician *maqwom $>$ maqôm; this vocalization is confirmed by the Punic spellings macom (Poenulus 940A/930) and macum (Poenulus 940B) ${ }^{44}$. The vocalization banitî $(<*$ banáytî) may find support in the Canaanite form $b[a-n] i-t[i]$ (EA 292, 29) despite the uncertainties.

4-5. QNMY 'T KL MMLKT WKL 'DM 'L YPTH 'YT MŠKB Z W'L YBQŠ BN MNM K 'Y ŠM BN MNM (qenummiya 'atta kul mamlokût wekul 'adom 'al yiptah 'iyat miškob zè

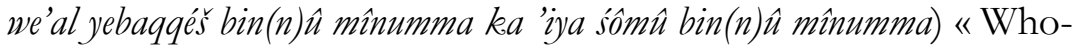
ever you are, king or (ordinary) man, may he (sid!) not open this resting-place and may he not search in it after anything because nothing whatsoever has been placed into it ». The first word of the sentence consists of the substantif qnm (or qn'm) and the interrogative pronoun $m y$, the whole being an equivalent of an indefinite pronoun "whoever (you are)». We vocalize the first word on the basis of the Syriac qunum "person ». In the interrogative pronoun the $-y$ is not a mater lectionis, but a full consonant. The presence of this $-y$ indicates that we have here the non-reduced form miya. In the Poenulus we find the reduced forms: $m i(m \hat{\imath}<* m i y u)$ et $m u(<* m \hat{o})^{45}$. Assuming the assimilation of the two mem, we could vocalize qenummiya. The vocalization 'atta « you» makes no diffi-

\footnotetext{
38 BAUER-LEANDER, p. 467 p.

${ }^{39}$ FRIEDRICH-RÖLLIG, \196 c.

${ }^{40}$ FriedriCH-RÖLLIG, \214.

${ }^{41}$ KOEHLER-BAUMGarTNER, sub voce hll 2 (p. 307).

42 BAUER-LEANDER, p. $458 \mathrm{~s}$.

43 BAUER-LEANDER, p. $491 \mathrm{~g}$.

${ }^{44}$ FRIEDRICH-RÖLLIG, \ 201-202.

${ }^{45}$ FRIEDRICH-RÖLLIG, $\int 120$.
} 
culty $^{46}$. We find an expression similar to qenummiya 'atta in the inscription of Tabnit (KAI 13) line 13 (miya 'atta kul 'adom 'és ...), and probably also in the inscription of Yehawmilk (KAI 10) line 11 ([qenummya 'attâ] kul mamlokût wekul 'adom 'és....), but in the latter the passage is restored on the basis of our inscription. The word $k l$ is a qull-type word (> kol in Hebrew) ${ }^{47}$. We would expect the vocalization kul (as in other Semitic languages), but the attested forms in Punic (Poenulus 935, 945) are cil, cel, chil, chy $t^{18}$. We will keep the vocalization $k u l(l)$ assuming a particular development for Punic $^{49}$. In Hebrew mamlâkâh and mamlâkut «kingdom, reign, dominion » are maqtal-type words ${ }^{50}$; this pattern becomes maqtol in Phoenician ${ }^{51}$, hence with the abstract ending mamlokit. The abstract form «kingdom» is used here for «king " ${ }^{52}$. The word 'dm ('âdâm in Hebrew) is a qatal-type word that becomes qatol in Phoenician $^{53}$, the vocalization is confirmed by the Punic form $a^{a d o m}{ }^{54}$. The prohibitive consists of the negation 'al followed by the jussive form yiptab (yaqtul with vowel -a- before the pharyngeal, then shift from $y a$ - to $y i$ - according to the Barth-Ginzberg law) from patal "open ». We observe a change in person: from the second ('atta) to the third person (yiptab). In Phoenician the nota accusativi is attested with two spellings: ' $y t$ and 't (Standard Phoenician and Punic). The first occurrence of the spelling ' $y t$ is found in the funeral inscription of Cyprus ( $K A I 30$, lines 3 et 6$)$ towards the end of the ninth century ${ }^{55}$. In ' $y t$ the $y$ is not a mater lectionis but a full consonant. Given the situation in Aramaic where the word is pronounced $y a \hat{t}$, we can propose 'iyat as primitive vocalization ${ }^{56}$. But how can we explain the later forms: 't in Standard Phoenician, and $e t, y t h$ in Punic (Poenulus 940B, 945, 940A/930, 932, 935, 936, with variants)? The development is probably similar to what happened to $k u l(l)$ «all». We see that there has been a weakening of kul to kèl or kil (Poenulus 945/935: cil, cel, chil, chyl). In the case of the nota accusativi there would have been a shift from 'iyat to 'ot, and thence (similarly to what happened to kul) to 'et or 'it ${ }^{57}$. In Hebrew miskâb is a miqtal-type form ${ }^{58}$, which becomes miqtol in Phoenician $^{59}$ : miskkob "place of lying, couch». The verb $b q s$

\footnotetext{
${ }^{46}$ FRIEDRICH-RÖLLIG, \ 111; MEYER, \ 30.

47 BAUER-LEANDER, $455 \mathrm{f}$.

48 FRIEDRICH-RÖLLIG, \192bis c.

${ }^{49}$ A particular development is also attested for the nota accusativi, see below.

${ }^{50}$ BAUER-LEANDER, p. $490 \mathrm{a}$.

${ }^{51}$ FRIEDRICH-RÖLLIG, \201: see for example marob (Poenulus 933) = ma'rob « guarantee ».

${ }^{52}$ FRIEDRICH-RÖLLIG, $₫ 200$ a.

53 BAUER-LEANDER, $461 \mathrm{~m}$; FRIEDRICH-RÖLLIG, \196a.

${ }^{54}$ J.M. REYNOLDS - J.B. WARD PERKINS, The Inscriptions of Roman Tripolitania, Rome - London, 1952, 879, 1.

55 FRIEDRICH-RÖLLIG, \255-256 and 79bis.

${ }^{56}$ FRIEDRICH-RÖLLIG, \256; TSSI, p. 30 prefers the form 'iyyat.

57 This is the explanation given in FrIEDRICH-RÖLLIG, \256. See E. PUECH, « Note sur la particule accusativale en phénicien », Semitica 32 (1982), p. 51-55.

58 BAUER-LEANDER, p. $490 \mathrm{z}$.

${ }^{59}$ FRIEDRICH-RÖLLIG, \200-201.
} 
«search» is used in the piel in Hebrew. We could reasonably assume that it is also used in the intensive form in Phoenician, hence the vocalization yebaqqés (there is only one occurrence in Phoenician). The preposition $b i$ - is followed by the $3 \mathrm{rd} \mathrm{m}$. sg.

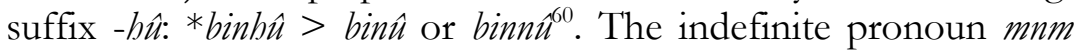
(attested five times in Phoenician and Punic ${ }^{61}$ ) corresponds to the Ugaritic mnm and Akkadian minumma or minummê « whatever». We may maintain the vocalization minumma. We assume that the conjuction ka has kept the primitive vowel $-a$ (in Punic, due to a particular development, ka became ke [see ce and chy in Poenulus 935]). The negation ' $\hat{\imath}$ is attested elsewhere in the Semitic languages: it is frequent in Ethiopic, rare in Biblical Hebrew (' $\hat{\imath}$-nâq «non-innocent» in Job 22:30 hapax), but common in Mishnaic

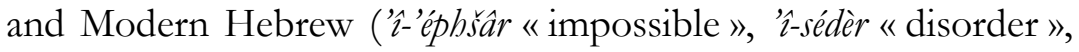
etc.). Since the matres lectionis are still unknown, we vocalize 'iya

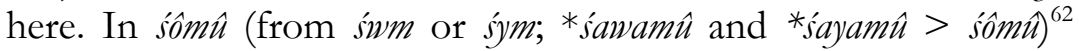
" they put ", $s$ represents $s$ (also in $n s$ ' four words below). The expression '厃̂ mînumma means «nothing ».

5-6. W'L YŠ' 'YT HLT MŠKBY W'L Y'MSN BMŠKB Z 'LT MŠKKB ŠNYY (we'al yišso' 'iyat ḅallot miškobiya we'al ya 'musén bimiškob zè 'alôt miškob šeniy) "And may he not move the coffin of my resting-place, nor carry me away from this resting-place to another resting-place ». As in Hebrew the first radical nun in $n s$ ' " raise, lift», here an imperfect, is assimilated and causes the reduplication of ś: *yinśa'> *yiśśa' and finally yiśso'. The final vowel of lamed-alef verbs is - $\hat{o}$ as shown by the spellings nasot and corathi $\left(=\right.$ carothi) in Poenulus $(947 / 937,940 / 930)^{63}$. In Punic we have two occurrences of the verb ' $m$ s in the nifal with the meaning «be carried away ${ }^{64}$. Here it would be the only occurence for the qal, more precisely the jussif (yaqtul) followed by the 1st m. sg. suffix with the connectig vowel -é-, hence ya'musénî. In the context the preposition $b i$ - does not have its original meaning « in, within », it means «(far) from», as in Abibaal (KAI 5) lin. 2. The ordinal šenty has the meaning here of « other» and not « second» as we would expect. We may vocalize it as in Hebrew ${ }^{65}$.

6. 'P 'M 'DMM YDBRNK 'L TŠMe BDNM ('ap 'ìm 'adomim yedabberûnakâ 'al tišma' baddanôm) "Also if men talk to you do not

${ }^{60}$ Friedrich-RÖllig, \254 I a; GIBSON, TSSI, p. 110. In note 5 Friedrich-Röllig say: "The prepositions $b$ - and tht before suffixes are lengthened with - $n$; see Hebrew tabténiy "beneath me » in 2 Sam 22:37.40.48 and tabtènnah « in her place» in Gen 2:21. There is still no explanation for this phenomenon ».

${ }^{61}$ DNWSI, p. 661

${ }^{62}$ FRIEDRICH-RÖLLIG, $\ 167$ and 46b.

${ }^{63}$ FRIEDRICH-RÖLLIG, $\ 170,172$.

${ }^{64}$ DNWSI, p. 872. The verb is also attested in Hebrew (nine times: seven in the qal and two in the hifil) with the meaning "carry a load, load (upon ass)». It is not necessary to assume with GIBSON, TSSI, p. 110, that the verb is used here in the piel. His hypothesis is based on Ugaritic where we find the piel participle ( $m^{\prime} m s$ ), see J. TROPPER, Ugaritische Grammatik (Alter Orient und Altes Testament 273), Münster, 2000, p. 554 and 563.

${ }^{65}$ FRIEDRICH-RÖLLIG, \ 244. 
listen to their chatter ». With the words 'ap 'im a new conditional proposition begins. The conjunction 'ap is frequent in Hebrew, and also in Phoenician (Archaic, Standard, Punic, and Neopunic), on the other hand the synonym gam (Hebrew, Moabite, Sam'alian) is absent from Phoenician ${ }^{66}$. The verbal form ydbrnk (from dibbér « to talk » piel as in Hebrew) consists of the 3 pl. long imperfect followed by the $2 \mathrm{~m}$. sg. suffix. The long imperfect (with a present-future meaning) is identifiable by the ending $-\hat{u n}-^{67}$. Assuming that the connecting vowel before a suffix is $-a$ - (see the form ti-mi-tu-na-nu = timitûnanû « you have killed us [litteraly «you have made us die»]» in El-Amarna ${ }^{68}$ ), we could vocalize yedabberûnakâ «they (will) talk to you». The construction dibbér with an objective suffix for the person is rare in Hebrew. Usually the verb is used with a preposition ('él, $l^{e}$, 'ét, ' $i m$ or $b^{\prime}$ ). It seems that Gen 37:4 (" they hated him and could not speak to bim $\left[d a b b^{e} r o\right]$ on friendly terms $\left.»\right)$ is the only one example of the use of a suffix for the person with this verb ${ }^{69}$. For 'al tisma', "do not listen ", we can compare 'al yiptah (line 4 , but here in the $2 \mathrm{~d} \mathrm{~m}$. sg.). $b d n m$ is generally explained as the substantive $b d$ with $3 \mathrm{rd} \mathrm{m}$. pl. suffix. The suffix should be read -nom, more precisely here -anom with the connecting vowel $-a$ - for the accusative. The vocalization of the suffix is known via the transcription labunom = la-'abûnom "for their father $»^{70}$. The presence of the nun before the suffix -ôm $(<* V$ bum $)$ is still largely unexplained ${ }^{71}$. The word bad «idle talk» is known in Hebrew, see Isa 16:6 and Jer 48:30 (« his idle boasts »); Job 11:3 (« boasts »); 41:4 (« his limbs ») (add conjectures for some other passages ${ }^{72}$ ). It is also attested in Syriac $b^{e} d \hat{o}$ («to contrive, to chatter »), bedyô («nonsense, invention»). We could vocalize baddanôm, with reduplication of the second consonant before a suffix as in Hebrew. Others have proposed to correct the text ${ }^{73}$, and to read either dbrnm (dabor «speak») or bdbrnm. This is not necessary, especially as concerns the second proposition since after tisma " the preposition bi- (that would give the word the meaning "obey", as in Hebrew) is not suitable to the context.

6-9. KKL MMLKT WKL 'DM 'Š YPTH 'LT MŠKB Z 'M 'Š YŠ' 'YT HLT MŠKBY 'M 'Š Y'MSN BMŠKB Z 'L YKN LM MŠKB 'T RP'M W'L YQBR BQBR W'L YKN LM BN WZR' THTNM (kakul mamlokût wekul 'adom 'és yiptah 'alôt miškob zè 'im 'és yis'śo' 'iyat ballot miškobiya 'îm 'és ya'musénî bimiškob zè 'al yakûn lôm miškob 'ét rapa'îm we'al yiqqaberû biqabr we'al

${ }^{66}$ FRIEDRICH-RÖLLIG, \257 b.

${ }^{67}$ FRIEDRICH-RÖLLIG, $\ 135$ a.

${ }^{68}$ FRIEDRICH-RÖLLIG, $\int 188$.

${ }^{69}$ KOEHLER-BAumgartNeR, p. 202, which also refers to our inscription.

${ }^{70}$ FRIEDRICH-RÖLLIG, \29 c, \112 (and note 2), \234 (p. 156).

71 J. Huennergard, "The Development of the Third Person Suffix in Phoenician », Maarav 7 (1991), p. 183-194.

${ }^{72}$ KoEHLER-BaumgarTNER, p. 105.

${ }^{73}$ For example Cook, Donner-Röllig, Segert, Bron, Puech, all the references are in DNWSI, s. v. bd 3. 
yakûnû lôm bin wezar" tabténôm) "For every king and every (ordinary) man, who will open what is above this resting-place, or will lift up the coffin of my resting-place, or will carry me away from this resting-place, may they not have a resting-place with the Rephaïm, may they not be buried in a tomb, and may they not have a son or offspring after them ». Compared to the preceding lines, only a few words are original here. The particle 'îm, in 'ím 'és (also line 10), has lost its original meaning «if»; here it means 《or $\rangle^{74}$. We vocalize the preposition with the suffix as lôm $(<*$ labum). The common translation for Hebrew rphaim (always plural) is «shadows, spirits of the dead ». The etymology is nevertheless disputed: either from rapa'a «to cure, to heal» or more probably from rapaba «to be weak ${ }^{75}$. The word is also used in Ugaritic (either the god râpi'u « the healer» ou rapa'um [doubtful vocalization] "spirit of the dead»). We could vocalize here rapa'im. At the end of the inscription of Tabnit (KAI 13, lin. 7-8) we find a similar curse: 'al yakûn lakâ zar babayyîm tabt samš wemiskob 'ét rapa'îm " may there be for you no descendants in the life under the sun or resting-place with the Raphaim ». Here the verb yiqqaberu is a $3 \mathrm{rd} \mathrm{m}$. pl. nifal imperfective «they will be buried ». We put the verb yakun $\hat{u}$ in the plural, although the singular could be justified since the two following subjects may be considered as collectives. For the connecting vowel between tabt (qatltype as in Hebrew, Arabic) and the suffix -nôm, we choose the vowel of the construct state plural $-\dot{e}^{-}$as in Hebrew, hence: tabténôm « beneath/after them ».

9-12. WYSGRNM H'LNM HQDŠM 'T MMLK $<\mathrm{T}>$ 'DR 'Š MŠL BNM LQȘTNM 'YT MMLKT 'M 'DM H' 'Š YPTH 'LT MŠKB Z 'M 'Š YŠ' 'YT HLT Z W'YT ZR' $M M L<K>T$ T' 'M 'DMM HMT 'L YKN LM ŠRŠ LMT WPR LM'L WT'R BHYM THT ŠMŠ (weyasgirûnôm hâ'alônim haqqadošim 'ét mamlokîu $<>$ 'addîr 'éš môsél bin(n)ôm laqișsotinôm/ laqasșôtinôm 'iyat mamlokût 'im 'adom bû'a 'és yiptah 'alôt miškeob zè 'îm 'ésyiśso' 'iyat hallot zè we'iyat zar' mamlo<kû̀ t bû'a 'im 'adomîm bumatu 'al yakûnû lôm šurš lamatțô we parî lama lô wetu'r babayyîm tạt šamš) "And may the sacred gods deliver them to a mighty king who will rule them in order to exterminate them, the king or this (ordinary) man who will open what is over this resting-place or will lift up this coffin, and (also) the offspring of this king or of those (ordinary) men. They shall not have root below or fruit above or appearance in the life under the sun ». We must be careful not to interpret the form aysgrmm as a consecutive imperfect (wayyiqtol after prohibitive forms as in Hebrew): it is merely a coordinated jussive with the $3 \mathrm{~m}$. pl. suffix, the waw having no energic function. The verb sagar is attested twice in Phoenician (here and again in line 21). We may hesitate between a yifil or a piel. Both are attested in Hebrew for this verb. However, the hifil is more frequently

\footnotetext{
${ }^{74}$ DNWSI, p. 69 (under B 1).

75 See the discussion in KOEHLER-BAUMGARTNER, p. 1188-1189.
} 
used. So we could vocalize yasgirûnôm (yifil) ${ }^{76}$ or yesaggerûnôm (piel). The meaning is «to deliver (to someone's power)». The preposition 'ét therefore means «to »; it is not the nota accusativi (always written ' $y t$ in this inscription). Note that in the expression hâ'alôim haqqadošim " the sacred gods", the two words carry the article, unlike the second occurrence of the expression in line 21 where only the adjective has the article. The vocalization 'alonim is based on the form alonim found in Poenulus 940/930. For the article we assume a compensatory lengthening ( $\left.h a_{-}->b \hat{a}\right)$, regular in Hebrew before alef. The adjective $q d s^{2}$ "sacred, holy» is a qatultype adjective ${ }^{77}$. We have no example of what this type becomes in Phoenician, but we could consider, by analogy with the qulltype, that it remains identical, hence haqqadosim (with reduplication of the first consonant after the article as in Hebrew). The adjective 'addî "powerful» is a qattîl-type adjective, which remains identical in Phoenician as we can see from the following names: Abaddir (< 'ab-'addîr), Baliddir (< ba'l-addîr), Aderbal $\left(<\right.$ 'addir ba') or Rusad(d)ir (toponym) ${ }^{78}$. It has here a masculine form because, despite its feminine form, the word mmlkt means «king» and not "kingdom». Gibson ${ }^{79}$ thinks that the powerful king here in question could be a euphemism for the «king of the death ». The verb $m s \xi$ II «dominate, rule» (msll I «compare» is not appropriate in the context) is well attested in Hebrew in the qal and in the hifil. But the tense is problematic: we expect to find an imperfect form: «a powerful king who will rule over them ». Instead of that, we find what could be a perfect form mašal. Gib$\operatorname{son}^{80}$ analyzes it as a prophetical perfect (known in Hebrew). This interpretation does not fit the context: we can hardly qualify the context as prophetic. The "prophetic perfect is not a special grammatical perfect, but a rhetorical device ", as underlined by Joüon $^{81}$. We could add: a rhetorical device in a prophetic context. It is better to understand the form as a participle with a future meaning, and to vocalize môsép ${ }^{2}$. Known in Hebrew the word " end » appears in three forms: qés, qâsééh, and qâsâh. Words of the qill-type ${ }^{83}$ remain qill, the feminine form of which is qillot, hence qișsot, and with the $3 \mathrm{~m}$. pl. suffix laqișotinom (with the connecting vowel $-i$ - of the genitive ${ }^{84}$ ) « for their end », i.e. «so they die ». It could also be a verb, in this case an infinitive construct of $q s h$ with

\footnotetext{
${ }^{76}$ FrIEDRICH-RÖLLIG, $\ 1907$ a, see also KAI, p. 22.

77 BAUER-LEANDER, p. 467 p.

${ }^{78}$ FRIEDRICH-RÖLLIG, \} 1 9 9 .

79 TSSI, p. 111.

80 TSSI, p. 111.

81 P. JOÜON - T. MuraOKA, A Grammar of Biblical Hebrew, Roma, 2006, \ $112 \mathrm{~h}$.

${ }^{82}$ For DNWSI, p. 702, it is also a participle. On the temporal sphere of the participle in Phoenician (present or future, the context always guides the interpretation), see FRIEDRICH-RÖLLIG, $\ 271$. «The use of the participle to express the near future and the future in general is an extension of the use of the participle as present », JOÜON-MURAOKA, \123 e.

83 BAUER-LEANDER, p. $454 \mathrm{~d}$.

${ }^{84}$ With GIBSON, TSSI, p. 111, but piel for KAI, p. 22, DNWSI, p. 1022, and FRIEDRICH-RÖLLIG, \233.
} 
an objective suffix «to kill them »: either qal (laqasôtinôm $\left.{ }^{85}\right)$ or piel (laqașsotinôm), both forms being used in Hebrew. The independent $3 \mathrm{rd} \mathrm{m}$. pl. personal pronoun appears as bumatu ${ }^{86}$. The substantive $s^{r} r{ }^{r}$ « root» is a monosyllabic qutl in Hebrew ${ }^{87}$, which remains identical in Phoenician, hence šuršs. We may find a confirmation of this in the Greek spelling overs/ooreıs (Dioscorides II, 163). The two adverbs $l m t$ and $l m l$ correspond to each other: "above » and «below». The Hebrew cognates are lemattah and lemalah, two words of the maqtal form ${ }^{88}$. Maqtal becomes maqtol in Phoenician as has already been seen (see mamlokut above). The first form is constructed from the root $n t h$ " to stretch out, to spread out, to extend» and the second on the root " $/ h$ " to go up, to ascend». We could vocalize lamatțô and lama 'lô respectively. The substantive $\operatorname{pr}$ (priy in Hebrew) "fruit» is a monosyllabic noun (in Hebrew there has been an assimilation of the vowel to the yod, hence *pary $>{ }^{*}$ piry $>*_{\text {piriy }}>$ p $^{e}$ riy ${ }^{89}$ ). How can we vocalize the word in Phoenician? Probably pari, since qatl-type words remain identical. Neither the etymology nor the formation is clear for the Hebrew word tô'ar «appearence, form». Koehler-Baumgartner proposes, after reference to Bauer-Leander, a qutl formation ${ }^{90}$, which could produce tu'r in Phoenician. The expression bahayyim tabt sams already occurs in the inscription of Tabnit (KAI 13), lines 7-8 ${ }^{91}$. We vocalize bym as in Hebrew, assuming a similar reduplication of the yod: hayyim «life »; with the article, habayyim (virtual reduplication as in Hebrew), hence here babayyim. The expression tht $s^{2} m s$ (taht $\check{s} a m s$, two qatl-type words; it can be observed that there is no article before šamš) is frequent in Ecclesiastes (1:9: 'én kol-bâdâš tahat haššâmès [pausal form] "there is nothing new under the sun»). What does the expression "appearance in the life under the sun" mean? Probably: «to have fame, good name or dignity $»^{92}$. See $e$ contrario Isa 53:2: «For he grew up before him like a tender shoot, and like a root out of parched ground, he has no stately form or majesty that we should look upon him, nor appearance that we should be attracted to him $»^{93}$.

12-13. K 'NK NHN NGZLT BL 'TY BN MSK YMM 'ZRM YTM BN 'LMT 'NK (ka 'anôkề nâhân nagzalti bilô 'ittiya bin masok yômîm 'az:îrim yatum bin 'almat 'anôkî) «For I who deserve mercy, I was carried away before my time, son of a limited

85 In Phoenician the infinitive construct has a feminine ending as in Hebrew, see the Punic transcription caneth $=$ qanôt $(-\hat{o}-$ becomes - é- in Punic); cf. FRIEDRICH-RÖLLIG, \ $178 \mathrm{a}$.

${ }^{86}$ FRIEDRICH-RÖLLIG, $\int 111$. The form is reconstructed on the basis of the comparative grammar of Semitic languages.

${ }^{87}$ BAUER-LEANDER, p. $460 \mathrm{~h}$.

88 See BAUER-LeANDER, p. 490 b and 492 o. The final -âh in Hebrew is a vestige of an ancient accusative, see BAUER-LEANDER, p. $527 \mathrm{r}$.

${ }^{89}$ BAUER-LEANDER, p. $577 \mathrm{~h}$.

90 KOEHLER-BAUMgartNer, p. 1545 (there are several other propositions), cf. BAUER-LEANDER, p. $460 \mathrm{~h}$.

${ }^{91}$ See our article cited in note 1.

${ }^{92}$ And not simply « beauty », as in Jer 11:16; Isa 52:14.

${ }^{93}$ Cited by GIBSON, TSSI, p. 111. 
number of short days (or: son of a limited number of days I was cut off), I an orphan, the son of a widow $»$. There is only one new element compared with lines 2-3: $n b n n$, which comes from the geminate verb bnn «to shew favour, to be gracious» (qal), «be pitied» (nifal) (attested twice in Phoenician: here and in a Punic text ${ }^{94}$ ). The only possible form here is the nifal participle the corresponding form of which in Hebrew would be nâhân (unattested as such in the MT) «deserving compassion, mercy». We propose to follow the Hebrew vocalization.

13-16. K 'NK 'ŠMN`ZR MLK SDNM BN MLK TBNT MLK ȘDNM BN BN MLK 'ŠMN'ZR MLK ȘDNM W'MY 'M'ŠTRT KHNT 'ŠTRT RBTN HMLKT BT MLK 'ŠMN'ZR MLK ȘDNM '[Š] BNN 'YT BT 'LNM 'YT [BT 'ŠTR]T BṢDN 'RṢ YM (ka 'anôkî̀ 'èsmûn'azar milk șidônim bin milk tabnît milk sîdônim bin bin milk ềmmûn'az̧ar milk sîdônîm we'ammaya 'amo'aśtart kôhant 'aśtart rabbotanû hammilkot bat milk

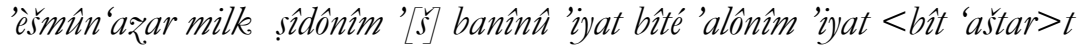
bișidon 'ars yim) «For I, Eshmunazar, king of the Sidonians, son of king Tabnit, king of the Sidonians, grandson of king Eshmunazar, king of the Sidonians, and my mother Amo[t]astart, priestess of Ashtart, our lady, the queen, daughter of king Eshmunazar, king of the Sidonians, (it is we) who have built the temples of the gods, [the temple of Ashtar]t in Sidon, the land of the sea ». We vocalize 'ammaya «my mother» with the connectig vowel $-a$ - for the nominative (subject of $b n n$ ). The personal name 'm'strt means « my mother is Astart» if we vocalize 'ammîastart, but many believe that the stonecutter has made a mistake here and has forgotten the letter - $t$ - after the mem. The name should be read 'mt'strt = 'amot'astart «maid of Astart». The word 'amot «maid» is indeed used to construct several names well attested in Phoenician such as A-ma-ti-ba-al, ${ }^{f}$ Amat(GEMÉ)-as-ta-ar-ti, Amotbal, Amobbal, Amotmicar ${ }^{95}$. But the aphaeresis ${ }^{96}$ of the $-t$ - is also attested in theophoric names with 'ếm ûn such as 'm'šmn and 'mšmn. In conclusion the two explanations are possible. 'Amot'aštart is said to be a daughter of 'Eshmunazar I; she is therefore half-sister of Tabnit. No doubt she was regent during the childhood of 'Eshmunazar II. This is confirmed by the fact that she was associated with major projects, as stated just below in the inscription. She was like the biblical gebîrâh (Athaliah for example). She bears the title of priestess of Astart: kôhant. The vocalization kôhant (qôtalt for the feminine participle) relies on the spelling kht attested in Archaic Phoenician ${ }^{97}$. This form could only be explained as the result of a total regressive assimilation of the nun before the feminine ending - $t$ - This assimilation would not have happened if the nun had carried a vowel, as in a Hebrew qôtèlèt-form.

${ }^{94}$ DNWSI, p. 389. We leave aside all the emendations proposed for our text.

${ }^{95}$ FRIEDRICH-RÖLLIG, $\ 2406$ (with references).

96 In the case of Amobbal, it is rather an assimilation $(t b>b b)$ than an aphaeresis of the taw.

${ }^{97}$ FRIEDRICH-RÖLLIG, \198 b. 
'Amot'aštart is also presented as rbtn hmlkt: rabbotanû hammilkot « our lady the queen » (just as the queen-mother, the gebîrâh). We vocalize rabbotan $\hat{u}$ with the connecting vowel $-a$ - (a nominative $)^{98}$ as suggested by the Greek transcription $\varrho v \beta \alpha \theta \omega \nu$ (rabbatôn $\left\langle\right.$ rabbatá-n $\hat{u}^{99}$ ). The vocalization bat «daughter» is warranted by the Neo-Punic spelling $b^{\prime} t$ where the 'ain represents the vowel $-a^{-100}$. The word ' $m$ is obviously an error made by the stonecutter for ' $s$, the relative pronoun ('és); all the commentators agree on this ${ }^{101}$. The verb banin $\hat{u}$ (from $b n b$ ) is a 1st pl. perfect qal « we have (re)built». The word $b t$ «house, temple» must be a plural here since several buildings are mentioned below, hence bîtê (but bâtê in Hebrew). The vocalization bit (or bett) is confirmed by the transcription Bi-ti-ru-me (Bit-rôm) ${ }^{102}$. What was the size of these buildings? Certainly not large constructions, but more probably little sanctuaries ${ }^{103}$. The city of Sidon is called 'rs ym « land of the sea » ('ars yim). In Hebrew 'rṣ is a qatl-type monosyllabic noun, hence 'ars. Since the word yam "sea » is a qall-type noun, we would expect a similar vocalization in Phoenician. However the transcriptions $^{104}$ lead us in another direction. The names $A s$-du-di-im-mu (Ashdod), In-im-me "spring of the sea", Qar-ti-me "city of the sea ", Da-la-im-me "gate of the sea ", I-si-bi-im-me, incite us to vocalize yim.

16-18. WYŠR'N 'YT 'ŠTRT ŠMM 'DRM W'NHN 'Š BNN BT L'ŠMN [Š]R QDŠ 'N YDLL BHR WYŠBNY ŠMM 'DRM W'NHN 'Š BNN BTM L'LN ȘDNM BṢDN 'RȘ YM BT LBL SSDN WBT L'ŠTRT ŠM B'L (weyốsibnû 'iyat 'astart šamém 'addîrim we'anabnû 'és banînû bît la'èsmûn <'sa>r qudš 'în

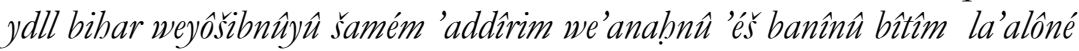
sîdônim bișidôn 'ars yim bît labal șîdôn webît la'aštart šim ba'l) "And we have placed Ashtart (in) the mighty heavens (or: in ShamemAddirim?). And it is we who have built a temple for Eshmun, the prince of the sanctuary of the source of Ydll in the moutains, and we have placed him (in) the mighty heavens (or: in ShamemAddirim?). And it is we who have built temples for the gods of the Sidonians in Sidon, the land of the sea, a temple for Baal of Sidon, and a temple for Ashtart, the Name of Baal». Everyone agrees in considering that the stonecutter has made an error: he has written wyšrn instead of wyšbn (there is just a small difference between the two letters), as shown by the repetition of the verb in line 17. The verbal form is a $1 \mathrm{st}$ pl. coordinate yifil perfect of yašab «to dwell, to sit»: weyôšibnû «and we have placed» (yốsib

${ }^{98}$ FrIEDRICH-RÖLLIG, $\int 233$. On the other hand GIBSON, TSSI, p. 66, who relies on the Greek transcription, prefers to vocalize rabbatôn( $\hat{u})$.

${ }^{99}$ We assume the following development: -*ánu > *-án > -ôn. For @v $\beta \alpha \theta \omega v$, see FrIEDRICH-RÖLlIG, \ 93; 97; 233; 237; 240 17b. Despite the spelling rabbatôn, we maintain the feminine ending rabbot, hence rabbotan $\hat{u}$.

${ }^{100}$ FRIEDRICH-RÖLLIG, $\int 1073$ (many examples are given).

101 See KAI, p. 22, and DNWSI, p. 1090 (lin. 6-7).

102 FRIEDRICH-RÖLLIG, \24111.

103 GIBSON, TSSI, p. 112.

${ }^{104}$ FrIEDRICH-RÖLLIG, \ 192 bis. 
$<*_{\text {yawsib }}<*^{*}$ yahawsib $)$. We have to supply the preposition $b i$ - before šamèm 'addîrim « in the mighty heavens » (unless it is a proper

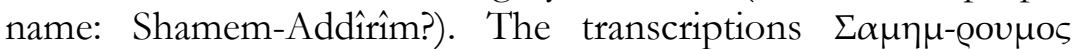
(= šamêm-rômîm) «exalted heavens", Ba-al-sa-me-me, Balsamem (Poenulus, 1027A $)^{105}$ indicate that the plural was pronounced šamêm $<$ *áamâm (after reduction of the diphthong). For 'addirim, see above. The restitution $\check{s}[r]$ is not unanimously accepted ${ }^{106}$. The word sar (here written with s) means "prince », as in Hebrew. It is a qall-type word (see for example šarru «king» in Akkadian) ${ }^{107}$, and remains identical in Phoenician. Also monosyllabic, but in the qutl form, $q d \check{s}$ « sanctuary » is to be vocalized quďs. After reduction of the diphthong -ay- ${ }^{108}$, ' $n$ « eye », here, « spring » must be read 'en or "in as shown by In-im-me "spring of the sea » (see above). In ordre to vocalize the word $h r$ "mountain », we can rely on the transcription Ha-ru-sa-pu-nu ("Mountain of the North») ${ }^{109}$, hence har. The spring of Ydll occurs again in the inscription of Baalshillem ${ }^{110}$ (but spelled Ydl there). Here it is located in the mountain, i.e. in the highest part of the city far from the shore. According to Gibson ${ }^{111}$ the title of 'Ešmûn here «prince of the sanctuary of the spring of Ydll in the mountain » recalls the title borne by senior officials in 1 Chron 24:5 "officers of God». There is however something odd about saying that a god is prince of a sanctuary as if he was his own officiant and official. Eshmunazar and his mother have installed 'Ešmûn in the mighty heavens (maybe a toponym, see above): weyôsibnûy $\hat{u}^{112}$ "and we have placed him». The primitive form of the word $s m$ «name» (here in the construct state) is $\operatorname{sim}^{113}$. As noted by DonnerRöllig ${ }^{114}$, the expression « Ashtart, the Name of Baal » occurs also in Ugaritic: "ttrt $\stackrel{s}{m} \mathrm{~m}$ b\%.

18-20. W'D YTN LN 'DN MLKM 'YT D'R WYPY 'RṢT DGN H'DRT 'Š BŠD ŠRN LMDT 'ṢMT 'Š P`LT WYSPNNM 'LT GBL 'RS LKNNM LṢDNM L'L[M] (we'ôd yatan lanû 'adôn milkîm 'iyat du'r weyapay 'arsôt dagôn hâ'addîrôt 'és bisadé sarôn lamiddot 'așûmot 'és pa'altî weyasapnûném 'alôt gubûl(é) 'ars lakûniném lașî́dônim la'ôlo $<m>$ ) « Moreover, the lord of kings gave us Dor and Joppa, the mighty lands of Dagon, which are in the plain of Sharon, as a reward for the brilliant action I did. And we have annexed them to the boundary of the land, so that they

105 FRIEDRICH-RÖLLIG, \ 76; 79; 86 a; 192; 222 b.

106 DNWSI, p. 1190. We shall just mention the interpretation of the word as an active participle of $5 w$ « to keep, to guard», hence "the guardian of the sanctuary $»$.

107 BAUER-LEANDER, p. $453 \mathrm{w}$.

108 FRIEDRICH-RÖLLIG, \86 a.

${ }^{109}$ FRIEDRICH-RÖLLIG, \} 1 9 2 \text { bis. }

110 GIBSON, TSSI, p. 114-116 (not in KAI).

111 GiBSON, TSSI, p. 113.

${ }^{112}$ For the form of the verbal suffix, see FRIEDRICH-RÖLLIG, $\int 190$.

113 J.-C. HAELEWYCK, Grammaire comparée des langues sémitiques. Eléments de phonétique, de morphologie et de syntaxe (Langues et cultures anciennes 7), Bruxelles, 2006, \ 215.

${ }^{114} \mathrm{~K} A I$, p. 23. 
would belong to the Sidonians for ever». The adverb ' $d$ «still, even, yet» (in Hebrew 'ôd) is originally a qâl-type substantive ${ }^{115}$; $-\hat{a}$ - becoming $-\hat{o}-$ in Phoenician ${ }^{116}$, we vocalize $\hat{o} d$. In Punic the word ' $d n$ «lord» appears with the spelling donni (='adôn lord » Poenulus, 998). We therefore vocalize 'adôn, and this vocalization is confirmed by the development of a qatâl-type ${ }^{117}$ word in Phoenician. The lord of the kings can only be the Persian king. In Akkadian, the name of Dor is $d u-u^{\prime}-r u$, which leads us to a vocalization $d u^{\prime} r$. In the cuneiform documents Jaffa/Joppe is known with the following spellings: $y a p u, y a p u, y a p p \hat{u}^{118}$. How can one vocalize the Phoenician form with a final yod? We could start

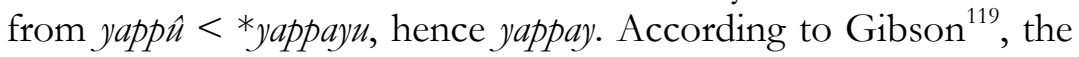
cities of Dor and Jaffa were given to the Phoenician king by Artaxerxes I (465-424) as a reward for his naval help during the wars against the Greeks (the Median wars). The two cities are qualified as 'arșôt dagôn hâ'addîrôt. The divine name Dagon (in Babylonian Dagana or Daguna) is mentioned several times in the Old Testament as Dagôn, god of the Philistines, god of Gaza (Judg 16:23) or Ashdod (1 Sam 5:1-7; cf. 1 Chron 10:10). The expression «mighty lands of Dagon » echoes the fertility of the soil in the coastal area. Regarding the etymology of Dagon, two solutions are possible. Either a proximity with the Hebrew dâgân « corn, grain »: Dagan would be a vegetation-god (that is precisely

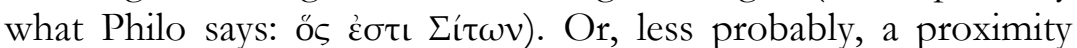
with the plural of $d \hat{a} g$ « fish »: Dagan would be a fish-god ${ }^{120}$. The word śd (written here with š) « plain » is well known from Hebrew (śâday, commonly sâdèh). It is a qatl-type word: *'sady has become sadé, as indicated by the transcription $\sigma \alpha \delta \varepsilon$ in Dioscorides (I, 97; III, 96) ${ }^{121}$. The fertile ${ }^{122}$ Plain of Sharon spreads out between Jaffa and the Carmel. The gift of the Persian king was so appreciated by Eshmunazar that he considers it worth mentioning in his inscription. In $l m d t$ we can recognize the feminine substantive $m d b^{123}$ "measure» (construct state). The Hebrew cognate is middâh " measure ", and not middéy (< min + day "sufficient measure ») as suggested by Friedrich-Röllig ${ }^{124}$. It is a qill-type word, which re-

\footnotetext{
115 KOEHLER-BAUmgartner, p. 752 refers to BAUER-LEANDER, p. $451 \mathrm{n}$.

116 FRIEDRICH-RÖLLIG, $₫ 79$ a.

117 BAUER-LEANDER, p. $469 \mathrm{f}$.

118 KOEHLER-BAUMGARTNER, p. 405.

119 GIBSON, TSSI, p. 113. An example is given by Pseudo-Scylax: Tyr would have obtained coastal cities in similar circumstances, cf. M. AVI-YONAH, The Holy Land from the Persian to the Arab Conquest, Grand Rapids (Michigan), 1966, p. 27ss.

${ }^{120}$ Cf. KOEhler-BAumgartner, p. 205.

121 FRIEDRICH-RÖLLIG, \195 e; cf. BAUER-LEANDER, p. 502 d ( -ay is certainly part of the root», but there is no certainty, cf. KOEHLERBAUMGARTNER, p. 1218-1219).

122 See Cant 2:1: «I am the rose of Sharon, the lily of the valleys ».

123 DNWSI, p. 595-596 (which mentions the hypothesis of Lipiński followed by others: the word could mean «tribute »).

${ }^{124}$ FRIEDRICH-RÖLLIG, $\ 252$ (the form should have been $m d y t$, since day comes from dayy).
} 
mains identical in Phoenician, thus with the feminine ending middot, and in the context lamiddot « in proportion to, as reward for». Hebrew attests an adjective 'asûm "mighty», which is a qatûl-type adjective ${ }^{125}$. Words of this type remain identical in Phoenician, as we know from the name Ba-('a)-al-ba-nu-nu (Ba'l+ hanûn "Baal is merciful ») ${ }^{126}$, hence 'așûmot (feminine singular). In the context it is an adjectival noun: "mighty deed, brilliant action ». In Hebrew the verb yâsap is either qal or hifil always with the meaning «to add». Two vocalizations are therefore possible: weyasapnûném (1st pl. qal with the suffix -ném), or weyôsipnûném (yifil, see weyôsibnûyu above). According to the grammar the suffix must be feminine (-ném) since the names of cities are feminine, but there are many exceptions (the suffix -nôm would have also have been justifiable). Note the change in persons: «I did ... we have annexed ». The vocalization gubul « border, territory » is based on the Punic gubulim (Poenulus 938). If in Punic the original $\hat{u}$ (gubull is a qutûl-type word) is still attested, the chances are that it remained throughout the development of the Phoenician language ${ }^{127}$. Here we have either a singular (gubûl) or a plural (gubûlê) construct state. In lknnm the verb kin « to be » is an infinitive construct qal with the feminine suffixe -nêm "so that they are ", hence lakûninêm (with the connecting vowel $-i-)^{128}$. The word $l m$ « eternity» is a qâtal-type word (as indicated by Hebrew ${ }^{129}$ ) which became qôtol in Phoenician ${ }^{130}$.

20-21. QNMY 'T KL MMLKT WKL 'DM 'L YPTH 'LTY W'L Y'R 'LTY W'L Y'MSN BMŠKB Z W'L YŠ' 'YT HLT MŠKKBY (qenummiya 'atta kul mamlokût wekul 'adom 'al yiptah 'alôtiya we'al ya'ar 'alôtiya we'al ya'musénî bimiškob zè we'al yišso' 'iyat ballot miškobiya) "Whoever you are, king or (ordinary) man, do not open what is above me and do not uncover what is above me and do not carry me away from this resting-place and do not lift up the coffin of my resting-place ». This is mainly a doublet of lines 4-6. Only the verb ' $y$ " « to denude, to uncover» is new. This verb, here a piel imperfect (jussive) to be vocalized $\mathrm{ya}^{\mathrm{a}} \mathrm{ar}{ }^{131}$ (*yugalliyu $>$ *yugalliy $>$ *yagalliy $>$ *yagallèb $>$ yagall for the apocopated form $>$ yagal [since a word does not end with a double consonant]), occurs only here in Phoenician.

\section{1-22. LM YSGRNM 'LNM HQDŠM 'L WYQṢN HMMLKT H' WH'DMM HMT WZR'M L'LM (lamâ yasgirûnôm 'alônîm haqqadošrm 'illè weyeqașșuna hammamlokût bû'a wehâ'adomîm bumatu wezarôm la ôlom) "Otherwise, the sacred gods will deliver them and cut off this king and those (ordinary) men and their offspring for ever ». The conjunction lamâ consisting of}

\footnotetext{
125 BAUER-LEANDER, p. $471 \mathrm{u}$.

${ }^{126}$ FRIEDRICH-RÖLLIG, \197 c.

127 So also $K A I$, p. 23.

${ }^{128}$ FRIEDRICH-RÖLLIG, \} 1 9 0 \text { 8, cf. \} 2 3 3 .

129 BAUER-LEANDER, p. 475 p.

${ }^{130}$ FRIEDRICH- RÖLLIG, $\ 198$.

131 With FrIEDRICH-RÖLLIG, \ 177 a. Cf. BAUER-LEANDER, p. 412 a.
} 
the preposition $l a$ - and the interrogative pronoun for things $-m \hat{a}$, means strictly speaking "why ", but here "so that ... not, otherwise ». Compared to line 9, in 'alônîm haqqadosìm 'illè only the adjective carries the article (the noun is sufficiently determined by the demonstrative pronoun). The vocalization of the demonstrative pronoun plural 'illè ( $<$ *'ilay) is based on the Punic transcriptions illii, ily (Poenulus 938) showing that it consists of two syllabes as in Hebrew ${ }^{132}$. Coordinated to the preceding verb, yqs $n$ is an imperfective piel of $q s h$ « to cut off». Others propose to analyze it as a qal imperfect meaning «to perish ». Hebrew uses the piel of qsh (the qal occurs in Hab 2:10, but the meaning is not clear ${ }^{133}$ ). We choose therefore a piel form: yeqașsina (< *yaqașûna

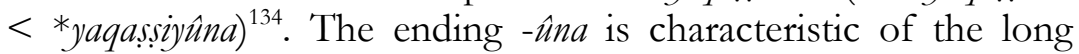
imperfect yaqtulîna.

\section{Syntactic observations}

Throughout the inscription we have noticed changes of persons: from the second to the third (lines 4-5), from the first singular to the first plural (line 19). In the indication of year, the word "year» is a plural while in Hebrew it is usually singular. We can note the indefinite pronouns: qenummiya «whoever» and minumma «whatever». The expression «they placed nothing» equals «nothing is placed» (line 5). We also note the peculiar use of the following words: bi- meaning «far from» (line 6), dibbér with an objective suffix for the person (line 7), 'im meaning « or » (lines 7 and 10), lamâ « why » meaning «so that ... not, otherwise » (line 21). The article is sometimes present sometimes absent in the expression "the sacred gods» (lines 9 and 21). The participle may express the future (môsél line 9, [not a prophetic perfect!]).

\footnotetext{
132 FRIEDRICH-RÖLLIG, \113 and 116.

133 See KOEHLER-BAUMGARTNER, p. 1046.

${ }^{134}$ KAI, p. 23; FRIEDRICH-RÖLLIG, \ 63 b; 135 a; 174; 177 b.
} 